\title{
The Transient Effect of Strict Glycaemic Control on B Cell Function in Newly Diagnosed Type 1 (Insulin-Dependent) Diabetic Patients
}

\author{
S. Madsbad, T. Krarup, O. K. Faber, C. Binder and L. Regeur \\ Hvidøre Hospital, Klampenborg, Denmark
}

Summary. Within $24 \mathrm{~h}$ of diagnosis, 15 consecutive Type 1 (insulin-dependent) diabetic patients were allocated at random to one of two treatment groups: group $\mathrm{A}(n=9$, mean age: 28 years, range: $17-35$ years) was treated conventionally with one or two daily doses of insulin; group $\mathrm{B}(n=6$, mean age: 27 years, range: $21-37$ years) was treated with nine daily injections of fast-acting insulin for ten days and thereafter conventionally as for group $\mathrm{A}$. The mean diurnal blood glucose concentration during the initial ten days of insulin treatment was $11.7 \pm 0.5 \mathrm{mmol} / \mathrm{l}$ (mean $\pm \mathrm{SEM}$ ) in group $\mathrm{A}$ and $6.4 \pm 0.3 \mathrm{mmol} / \mathrm{l}$ in group B $(p<0.01)$. Pancreatic B cell function was evaluated $1,7,14,90$, and 180 days after the start of insulin treatment from the C-peptide response to a standard meal. At one and seven days after diagnosis, no difference was found in $\mathrm{B}$ cell function between the two groups. After 14 days, the amount of C-peptide secreted during the test meal was $18.0 \pm 2.6 \mathrm{nmol}$ (mean \pm SEM) in group A compared with $29.0 \pm$ $3.6 \mathrm{nmol}$ in group B $(p<0.05)$. After 90 and 180 days, no difference was demonstrated in $B$ cell function. The maximal B cell function observed was similar in the two groups, but occurred earlier in group B (at 14 days) than in group A (at 90 days) $(p<0.05)$. This study indicates that strict initial glycaemic control may lead to an earlier improvement in B cell function, but that this improvement is of short duration.

Key words: Type 1 diabetes, B cell function, C-peptide, glycaemic control.

At the onset of disease, Type 1 (insulin-dependent) diabetic patients may still have some residual endogenous insulin secretion, as judged from C-peptide measurements [1, 2]. In the first few months after on- set, most patients exhibit increasing endogenous insulin secretion with a decreasing need for exogenous insulin [3-6].

Mirouze et al. [7] found a more frequent and sustained remission after short-term near normal blood glucose control using a closed-loop insulin infusion system. Their study consisted of 40 patients, of whom 12 were given intensive treatment and the remaining 28 were treated conventionally.

The aim of our study was to evaluate critically the effect of strict initial blood glucose control on B cell function in Type 1 diabetes compared with conventional treatment.

\section{Patients and Methods}

The patients were selected from those admitted to the Hvidøre Hospital between 1.1.1977 and 31.12.1979 according to the following criteria: clinical diagnosis within the previous $24 \mathrm{~h},>5 \%$ glycosuria, significant ketonuria $(\geqslant++$ with ketostix), body weight $<110 \%$ of the ideal for sex and height [8] and age under 40 years. None of the patients was in severe ketoacidosis or coma at the time of diagnosis. None had any disease other than diabetes and no medication was taken apart from insulin during the study. The clinical features of the patients at the diagnosis of diabetes are shown in Table 1. Eligible patients were given a detailed explanation of the study and, after giving informed consent, were allocated at random to one of two treatment groups. Two patients did not wish to participate. Nine patients were allocated to the group treated with conventional therapy (group A) and seven patients to the group with strict control of diabetes (group B). In group B, one patient withdrew after one day. Data from this patient are not included. In group $\mathrm{A}$, one patient did not attend for the test at 6 months. 
Table 1. Clinical characteristics of the patients at the diagnosis of diabetes

\begin{tabular}{|c|c|c|c|c|}
\hline & \multicolumn{2}{|c|}{$\begin{array}{l}\text { Group A } \\
(n=9)\end{array}$} & \multicolumn{2}{|c|}{$\begin{array}{l}\text { Group B } \\
(n=6)\end{array}$} \\
\hline & Mean & Range & Mean & Range \\
\hline $\begin{array}{l}\text { Age at diagnosis } \\
\text { of diabetes (years) }\end{array}$ & 28 & $17-35$ & 27 & $21-37$ \\
\hline $\begin{array}{l}\% \text { of ideal body } \\
\text { weight }\end{array}$ & 87.5 & $75-104$ & 93 & $80-104$ \\
\hline $\begin{array}{l}\text { Blood glucose } \\
\text { before start of } \\
\text { insulin treatment } \\
(\mathrm{mmol} / \mathrm{l})\end{array}$ & 18.1 & $14.0-25.8$ & 23.3 & $12.6-39.5$ \\
\hline $\begin{array}{l}\text { Total bicarbonate } \\
(\mathrm{mmol} / 1)\end{array}$ & 23.0 & $15.8-30.0$ & 19.8 & $7.0-29.6$ \\
\hline Sex M:F & & $6: 3$ & & $3: 3$ \\
\hline
\end{tabular}

Group A: conventionally treated; Group B: treated with multiple daily insulin injections for strict glycaemic control

On admission to the Hvidøre Hospital, the mean blood glucose was $15.9 \pm 1.5$ and $18.6 \pm 4.4 \mathrm{mmol} / 1$ ( \pm SEM), respectively in groups $A$ and $B$. Regardless of group, all patients were treated with low dose IM insulin from the time of admission until the following morning. All patients allocated to group A for conventional therapy were treated with long-acting Lente or Monotard insulins once or twice daily with or without soluble insulin (Actrapid). The dose of insulin was adjusted daily as needed: the dose of Monotard or Lente being adjusted every second day, and the dose of soluble insulin adjusted each day. Patients allocated to group B were given nine injections daily of fastacting insulin (Actrapid) with the aim of achieving normoglycaemia. Dosage was adjusted according to pre-injection blood glucose measurements (Reflotest) and by the glycaemic response to the previous day's insulin dose. Insulin was given IM pre-prandially and SC between meals. The timing and fractional doses of insulin were $0730 \mathrm{~h}(24 \pm 0.7 \%$, mean $\pm \mathrm{SEM})$, $0930 \mathrm{~h}(1 \pm 0.5 \%), 1115 \mathrm{~h}(20 \pm 0.7 \%), 1400 \mathrm{~h}(10 \pm$ $0.6 \%), 1700 \mathrm{~h}(18 \pm 0.6 \%), 2000 \mathrm{~h}(9 \pm 0.5 \%), 2300 \mathrm{~h}$ $(6 \pm 0.6 \%), 0200 \mathrm{~h}(6 \pm 0.4 \%)$ and $0500 \mathrm{~h}(6 \pm 0.5 \%)$. From day 11, patients from group $B$ were changed to conventional therapy as described for group $\mathrm{A}$. The patients were discharged 14 days after admission to hospital and were followed as out-patients by different physicians.

During the period in hospital, all the patients received an iso or hypercaloric diet, comprising $42 \%$ carbohydrate, $38 \%$ fat and $20 \%$ protein. $20 \%, 30 \%$ and $35 \%$ of the total caloric intake was given at breakfast, lunch and dinner, respectively, while snacks, each of $5 \%$, were given at 0930,1500 and $2100 \mathrm{~h}$. All patients were ambulatory.
Pancreatic B cell function was evaluated 1 (test 1 ), 7 (test 2), 14 (test 3 ), 90 (test 4 ) and 180 days (test 5) after admission to hospital from the $\mathrm{C}$-peptide response to a standard 490 calorie meal $(60 \%$ carbohydrate, $26 \%$ fat and $14 \%$ protein). The patients injected their morning insulin $10 \mathrm{~min}$ before eating. Peripheral venous blood samples were taken $-10,0,5,10,15,30$, $45,60,90,120,150$ and $180 \mathrm{~min}$ after beginning the meal, which was completed in $10 \mathrm{~min}$. On day 1 , blood samples were only taken before and $120 \mathrm{~min}$ after beginning the meal.

Insulin secretion during the meal was calculated from the total area under the plasma C-peptide curve from 0 to $180 \mathrm{~min}$, assuming a metabolic clearance rate of $310 \mathrm{ml} / \mathrm{min}$ [9]. For comparison, the response to the same meal was studied in ten normal subjects, similar in age and weight.

While in hospital, the degree of glycaemic control was assessed from the mean blood glucose of three pre-prandial $(0730 \mathrm{~h}, 1130 \mathrm{~h}, 1730 \mathrm{~h})$ and three postprandial $(1400 \mathrm{~h}, 2000 \mathrm{~h}, 0200 \mathrm{~h})$ whole blood glucose values. After discharge from hospital, fasting blood glucose on the day of investigation and glycosuria during the previous $24 \mathrm{~h}$ were used.

C-peptide was measured using antibody M1230 [10]. A plasma C-peptide concentration exceeding $0.05 \mathrm{nmol} / 1$ was taken to indicate continued B cell function [10]. The within and between assay coefficients of variation for the C-peptide assay were $3.2 \%$ and $9.6 \%$, respectively [10]. The cross-reactivity with human proinsulin is very low with this antibody. Thus, the proinsulin concentration has to exceed the normal fasting level by a factor of more than 200 before any proinsulin is measured as C-peptide [11]. Blood glucose was measured by a glucose oxidase method.

For statistical calculations, the Mann-Whitney rank sum test or Wilcoxon's test was used to compare mean concentrations. The level of type I error $(2 \alpha)$ was set at 0.05 .

\section{Results}

On the day of admission, the two groups were treated with a similar amount of insulin (group A: $0.76 \pm 0.09$ $\mathrm{IU} / \mathrm{kg}$, group B: $0.78 \pm 0.13 \mathrm{IU} / \mathrm{kg}$ ) (mean $\pm \mathrm{SEM}$ ). Thereafter, the average daily dose of insulin in group $\mathrm{B}\left(0.88 \pm 0.03 \mathrm{IU} \mathrm{kg}^{-1} 24 \mathrm{~h}^{-1}\right)$ (mean $\pm \mathrm{SEM}$ ) was significantly higher than in group A $(0.45 \pm 0.09 \mathrm{IU}$ $\mathrm{kg}^{-1} 24 \mathrm{~h}^{-1}$ ) during all 10 days of multiple injections $(p<0.01)$. Mean daily blood glucose concentrations decreased over a period of 10 days to about normal values in group B (average $6.4 \pm 0.3 \mathrm{mmol} / 1$ during the period with strict glycaemic control), whereas in 
Table 2. Daily dose of insulin and $24 \mathrm{~h}$ glycosuria 3 (test 4 ) and 6 (test 5) months after the diagnosis of diabetes

\begin{tabular}{lllllll}
\hline & & \multicolumn{2}{c}{ Test 4 } & & \multicolumn{2}{c}{ Test 5 } \\
\cline { 6 - 7 } \cline { 5 - 6 } & & Mean & Range & & Mean & Range \\
\hline Insulin dose & Group A & 0.28 & $0.12-0.41$ & 0.28 & $0.16-0.39$ \\
$\left(\mathrm{IU} \mathrm{kg}^{-1} 24 \mathrm{~h}^{-1}\right)$ & Group B & 0.30 & $0.05-0.81$ & 0.36 & $0.05-0.87$ \\
Glycosuria & Group A & 31 & $0-163$ & 16 & $0-74$ \\
$(\mathrm{~g} / 24 \mathrm{~h})$ & Group B & 6 & $0-154$ & 14 & $0-47$ \\
\hline
\end{tabular}

Group A: conventionally treated; Group B: treated with multiple daily insulin injections for strict glycaemic control

Table 3. C-peptide secretion and total area under blood glucose curve during tests $2,3,4$, and 5

\begin{tabular}{|c|c|c|c|c|c|c|c|c|c|c|}
\hline \multirow{3}{*}{ Test } & \multicolumn{4}{|c|}{ C-peptide secreted (nmol) } & \multirow{3}{*}{$p$} & \multicolumn{4}{|c|}{ Area under blood glucose curve $(\mathrm{mmol} / 1 \times \mathrm{min})$} & \multirow{3}{*}{$p$} \\
\hline & \multicolumn{2}{|c|}{ Group A } & \multicolumn{2}{|c|}{ Group B } & & \multicolumn{2}{|c|}{ Group A } & \multicolumn{2}{|c|}{ Group B } & \\
\hline & Mean & Range & Mean & Range & & Mean & Range & Mean & Range & \\
\hline 2 & 13.4 & $9.3-16.2$ & 14.5 & $3.8-24.9$ & NS & 2724 & $1640-3487$ & 1390 & $792-2443$ & $<0.05$ \\
\hline 3 & 18.0 & $9.4-29.6$ & 29.02 & $20.6-42.9$ & $<0.05$ & 2129 & $1439-3277$ & 2140 & $967-3370$ & NS \\
\hline 4 & 25.45 & $9.0-45.1$ & 24.73 & $6.5-46.4$ & NS & 2224 & $1726-2783$ & 2781 & $1595-4319$ & NS \\
\hline 5 & 18.7 & $5.7-35.6$ & 20.7 & $5.6-37.6$ & NS & 2969 & $1325-4491$ & 3190 & $2300-5312$ & NS \\
\hline
\end{tabular}

Group A: conventionally treated; Group B: treated with multiple daily insulin injections for strict glycaemic control Normal subjects: mean 55.2, range $37.5-71.6 \mathrm{nmol}$

Normal subjects: mean: 823 , range $656-866 \mathrm{mmol} / 1 \times \mathrm{min}$

group A, the mean daily blood glucose only improved slightly with values never below $9 \mathrm{mmol} / 1$ (average $11.7 \pm 0.5 \mathrm{mmol} / 1)$.

During the last 3 days in hospital, when both groups were treated conventionally, the average mean dáily dose of insulin in group $\mathrm{B}\left(0.32 \pm 0.03 \mathrm{IU} \mathrm{kg}^{-1}\right.$ $\left.24 \mathrm{~h}^{-1}\right)$ was significantly lower than in group $\mathrm{A}(0.46$ $\left.\pm 0.02 \mathrm{IU} \mathrm{kg}^{-1} 24 \mathrm{~h}^{-1} ; p<0.05\right)$, whereas no difference was found in glycaemic control between groups $\mathrm{A}$ and $\mathrm{B}$.

At 3 (test 4) and 6 months (test 5), the two groups showed the same degree of metabolic control, as evaluated from their fasting blood glucose (Fig. 1) and $24 \mathrm{~h}$ glycosuria (Table 2) and there was no difference in daily insulin dose (Table 2).

In the fasting state on day 1 , two patients in group $A$ and three patients in group B had insignificant amounts of plasma C-peptide. No significant difference in fasting $\mathrm{C}$-peptide was found between group $\mathrm{A}$ (mean $0.12 \mathrm{nmol} / 1$; range $0 .-0.22 \mathrm{nmol} / 1$ ) and group B (mean $0.08 \mathrm{nmol} / 1$; range $0-0.16 \mathrm{nmol} / \mathrm{l}$ ). The corresponding blood glucose values were mean: $10.2 \mathrm{mmol} / 1$; range: $4.7-12.8 \mathrm{mmol} / 1$, and mean: $6.4 \mathrm{mmol} / 1$, range: $2.8-15.3 \mathrm{mmol}$, respectively (NS). Two hours after the test meal, the C-peptide concentrations were group A: mean: $0.17 \mathrm{nmol} / 1$, range $0.06-0.41 \mathrm{nmol} / 1$ and group B: mean: $0.18 \mathrm{nmol} / 1$, range: $0.06-0.41 \mathrm{nmol} / 1$, respectively (NS).
Seven days after admission, the average amounts of C-peptide secreted in response to the test meal (test 2) were not different in the two groups (Table 3 , Fig. 1). However, the mean blood glucose concentration during the meal test was significantly lower at all points $(p<0.05)$ in group B than in group A (Table 3 , Fig. 1).

After 14 days (test 3), the amount of C-peptide secreted (Fig. 1 and Table 3 ) was significantly greater in group $\mathrm{B}$ than in group $\mathrm{A}(p<0.05)$.

In group $A$ at 3 months (test 4 ), the amount of $C$ peptide secreted (Table 3, Fig. 1) had increased by an average of $41 \%(p<0.05)$ compared with that on discharge from hospital (test 3 ). The amounts of C-peptide secreted at 3 (test 4 ) and 6 months (test 5) were not significantly different (Table 3, Fig. 1).

In group B at 3 months (test 4 ), a decrease in the amount of C-peptide secreted (Table 3, Fig. 1) was demonstrated in five out of six patients when compared with test 3 and a further decline in the amount secreted (Table 3, Fig. 1) was found in five out of six patients at 6 months (test 5) when compared with the test at 3 months (test 4 ).

No significant difference was found in the amount of C-peptide secreted between group $\mathrm{A}$ at 3 months and group B at 14 days, when each group achieved their maximal B cell function. In both groups, the maximal amount of C-peptide secreted was about $50 \%$ of the normal value (Table 3 ). 
Test 2


Blood glucose (mmol/l)

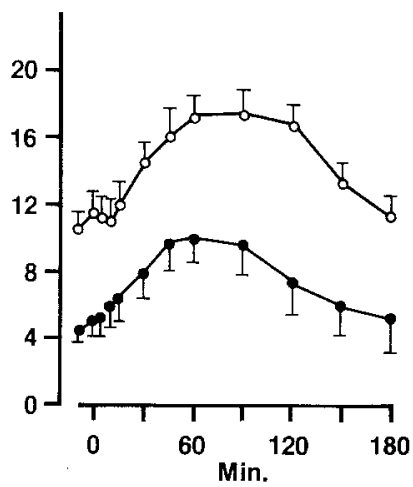

C-peptide (nmol/l)

Test 3

Blood glucose (mmol/l)

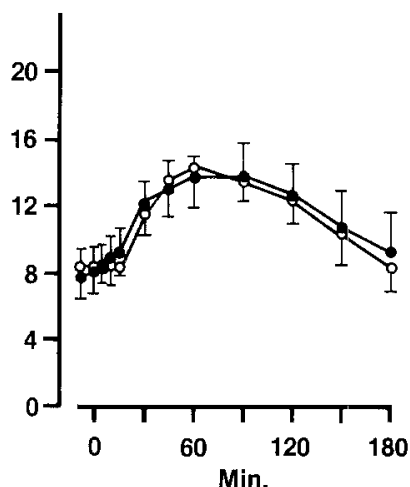

Test 4

Test 5



C-peptide (nmol/l)

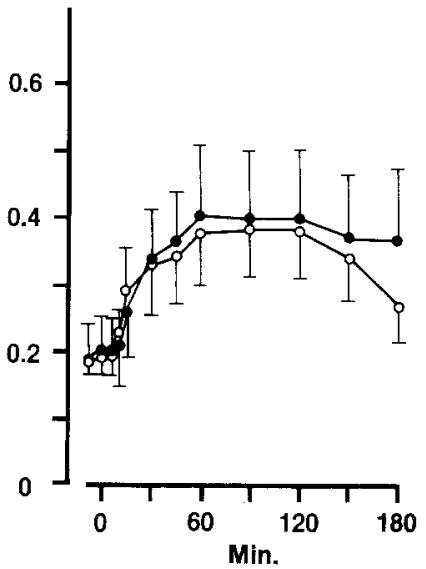

Blood glucose (mmol/l)

Blood glucose (mmol/l)
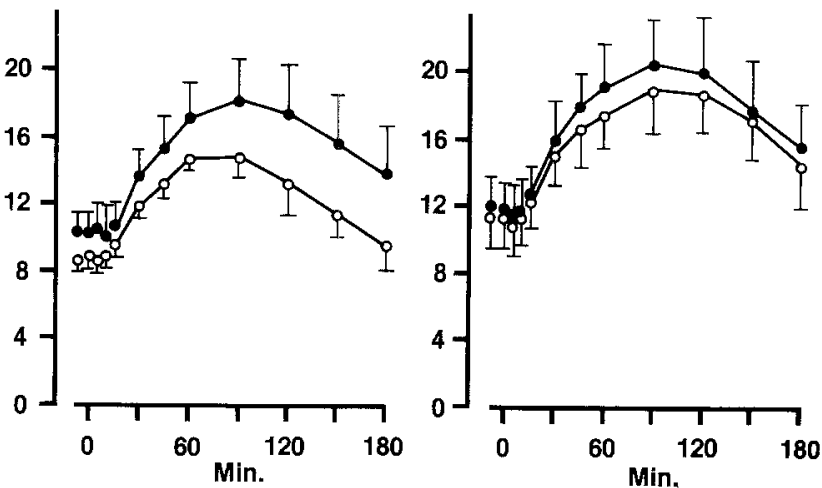

Fig. 1. Mean plasma C-peptide and blood glucose concentrations in response to a standard meal during tests $2,3,4$, and 5 (see text). $\bigcirc-\bigcirc$ group A, conventionally treated. group B, treated with multiple daily insulin injections. Results expressed as mean \pm SEM

\section{Discussion}

In Type 1 (insulin-dependent) diabetes, it is not uncommon to see a transient reduction in insulin requirements during the first few months after diagnosis $[1,3-6,12,13]$. This partial remission period is characterized by increased endogenous insulin secretion $[1,3-6,12,13]$.

All the patients in the present study improved their B cell function after the start of insulin treatment. Our results suggest that the initial degree of control has an important effect on the rate of improvement in B cell function. In the group treated with nine injections daily of fast-acting insulin, the degree of glycaemic control was close to that obtained with the open-loop insulin infusion system $[14,15]$. In this group, maximal B cell function was attained after 14 days of insulin treatment. In the conventionally treated group, a similar degree of B cell function was reached, but only after 3 months of insulin treatment.
In another group of insulin-dependent patients, we also found that maximal C-peptide values were attained between 2-5 months after the start of conventional insulin treatment [6].

The results also suggest that the favourable effect of strict glycaemic control is only temporary, because decreasing B cell function was found in group B after the period of strict glycaemic control and their discharge from hospital.

Three and 6 months after the onset of diabetes, similar B cell function was found in both groups. After their discharge from hospital, there were no significant differences in the degree of metabolic control between the two groups.

The results are in accordance with our earlier observations concerning patients with a duration of disease from $0.5-4$ years [16], where we demonstrated a $44 \%$ increase in insulin secretion after one week's treatment with multiple daily insulin injections. This declined, however, to its initial value 21 days later, 
when the subjects were outpatients in conventional therapy. In contrast with our results, Mirouze et al. [7] found that, after transient but excellent blood glucose control, B cell function improved more frequently than following conventional treatment. The explanation of these differing results is unclear, but Mirouze et al. [7] used a closed-loop insulin infusion system, while we used multiple injections of fast-acting highly purified porcine insulin. Our patients, after 2 days' treatment and over the following 8 days, had an average mean daily blood glucose value below $7 \mathrm{mmol} / 1$ (range: $6.8 \pm 0.4$ to $5.0 \pm 0.2 \mathrm{mmol} / \mathrm{l}$ ) compared with blood glucose levels varying from $60 \mathrm{mg} / 100 \mathrm{ml}$ fasting to $150 \mathrm{mg} / 100 \mathrm{ml}$ in the post-absorptive state in the study of Mirouze et al. [7]. Their patients were treated with continuous insulin infusion for $24 \mathrm{~h}$ periods using the artificial pancreas and thereafter by diet and hypoglycaemic agents for 2-3 days if they improved. Insulin treatment was re-instated if the patients relapsed or if only a light improvement was found another $12-24 \mathrm{~h}$ of insulin treatment was given. On average their patients were treated for $5 \pm 1$ days with the closed-loop system. Their patients also had a longer duration of diabetes before the induction of strict glycaemic control $30 \pm 6$ days; range 9-90 days). Furthermore, our study was a randomized controlled study.

The mechanism(s) which improve B cell function when hyperglycaemic stress is relieved are unclear. At the time of diagnosis of diabetes, the constant hyperglycaemic stimulus may have exhausted the B cells. Strict glycaemic control may then suppress endogenous insulin secretion and when the islets are stimulated, larger stores of insulin may have accumulated ready for secretion [17-20].

In the conventionally treated group, an improvement in metabolic control was also obtained during the first 14 days after diagnosis. This cannot be explained by intensified insulin treatment, because the daily dose of insulin was constant. It probably represents the combined effect of increased endogenous insulin secretion and a gradual decrease in insulin resistance accompanying the improved metabolic control of the patients after the start of insulin treatment [21].

\section{References}

1. Ludvigsson J, Heding LG (1978) Beta-cell function in children with diabetes. Diabetes 27:230-234

2. Krarup T, Madsbad S, Regeur L, Binder C, Faber OK (1979) Beta-cell function during initial treatment in insulin dependent diabetics. Acta Endocrinol 227 (Suppl): 44 (abstract)

3. Weber B (1972) Glucose-stimulated insulin secretion during 'remission' of juvenile diabetes. Diabetologia 8: 189-195

4. Block MB, Rosenfield RL, Mako ME, Steiner DF, Rubenstein
AH (1973) Sequential changes in beta-cell function in insulintreated diabetic patients assessed by C-peptide immunoreactivity. N Engl J Med 288: 1144-1148

5. Park BN, Soeldner JS, Gleason RE (1974) Diabetes in remission. Insulin secretory dynamics. Diabetes 23: 616-623

6. Faber OK, Binder C (1977) Plasma C-peptide during the first year of insulin-dependent diabetes mellitus. In: Bajaj JS (ed) Diabetes. Proceedings of the IX Congress of the International Diabetes Federation, New Delhi. Excerpta Medica, Amsterdam, pp 149-154

7. Mirouze J, Selam JL, Pham TC, Mendoza E, Orsetti A (1978) Sustained insulin-induced remissions of juvenile diabetes by means of an external pancreas. Diabetologia 14: 223-227

8. Natvig H (1956) New height-weight tables for Norwegian women and men. The National Society for Diet and Health, Oslo

9. Faber OK, Hagen C, Binder C, Markussen J, Naithani VK, Blix PM, Kuzuya H, Horwitz DL, Rubinstein AH, Rossing N (1978) Kinetics of human connecting peptide in normal and diabetic subjects. J Clin Invest 62: 197-203

10. Faber OK, Markussen J, Naithani VK, Binder C (1976) Production of antisera to synthetic benzyloxycarbonyl-C-peptide of human proinsulin. Hoppe Seyler's Z Physiol Chem 357: 751-757

11. Faber OK, Binder C, Markussen J, Heding LG, Naithani VK, Kuzuya H, Plix P, Horwitz DL, Rubinstein AH (1978) Characterization of seven C-peptide antisera. Diabetes 27: 170-177

12. Johansen K, Ørskov H (1969) Plasma insulin during remission in juvenile diabetes mellitus. Br Med J 1: 676-678

13. Parker ML, Pildes RS, Chao KL, Cornblath M, Kipnis DM (1968) Juvenile diabetes mellitus, a deficiency in insulin. Diabetes 17:27-32

14. Pickup JC, Keen H, Parsons JA, Alberti KGMM, Rowe AS (1979) Continuous subcutaneous insulin infusion: improved blood glucose and intermediary-metabolite control in diabetes. Lancet $1: 1255-1258$

15. Tamborlane WV, Shervin RS, Gene M, Felig P (1979) Reduction to normal of plasma glucose in juvenile diabetes by subcutaneous administration of insulin with a portable infusion pump. N Engl J Med 11:573-578

16. Madsbad S, Krarup T, Regeur L, Faber OK, Binder C (1981) Effect of strict glycaemic control on residual $B$ cell function in insulin dependent diabetes. Diabetologia 20:530-534

17. Andersson A, Westman J, Hellerström C (1974) Effects of glucose on the ultrastructure and insulin biosynthesis of isolated mouse pancreatic islets maintained in tissue culture. Diabetologia 10:743-753

18. Carpenter AM, Lazarow A (1967) Effect of hyper- and hypoglycemia on beta-cell degranulation and glycogen infiltration in normal, subdiabetic and diabetic rats. Diabetes 16:493-501

19. Frankel BJ, Schmid FG, Grodsky GM (1979) Effect of continuous insulin infusion with an implantable seven-day minipump in the diabetic Chinese hamster. Endocrinology 104: $1532-1539$

20. Turner RC, McCarthy ST, Holman RR, Harris E (1976) Betacell function improved by supplementing basal insulin secretion in mild diabetes. Br Med J 1: 1252-1254

21. Ginsberg HN (1977) Investigation of insulin resistance during diabetic ketoacidosis. Role of counterregulatory substances and effect of insulin therapy. Metabolism 26: 1135-1146

Received: 22 April 1981

and in revised form: 17 September 1981

Sten Madsbad

Hvidøre Hospital

Emiliekildevej 1

DK-2930 Klampenborg, Denmark 